\title{
Commentary: Serotonin Receptor 2B Mediates Mechanical Hyperal- gesia by Regulating Transient Receptor Potential Vanilloid 1
}

\author{
Yeu-Shivan Su ${ }^{1 *}$, and Wei-Hsin Sun ${ }^{1,2 *}$ \\ 'Department of Life Sciences, National Central University, Jhongli, Taiwan \\ ${ }^{2}$ Center for Biotechnology and Biomedical Engineering, National Central University, Jhongli, Taiwan
}

Article Info

\section{Article Notes}

Received: August 04, 2016

Accepted: September 09, 2016

\section{${ }^{*}$ Correspondence:}

Dr. Wei-Hsin Sun, Department of Life Sciences, National Central University, Jhongda Road 300, Jhongli, Taiwan 32054; Tel: 886-34275794, Fax: 886-3-4228482; E-mail: Weihsin@cc.ncu.edu.tw

(C) 2016 Wei-Hsin Sun. This article is distributed under the terms of the Creative Commons Attribution 4.0 International License

\begin{abstract}
Serotonin [5-hydroxytryptamine (5-HT)] is an inflammatory mediator which contributes to inflammatory pain. We previously demonstrated that 5-HTinduced mechanical hyperalgesia is mediated by $5-\mathrm{HT}_{2 \mathrm{~B}}$, but not by other $5-\mathrm{HT}$ receptors. Our recent article provided further evidence how $5-\mathrm{HT}_{2 \mathrm{~B}}$ regulates 5-HT-induced mechanical hyperalgesia, and suggested, that $5-\mathrm{HT}_{2 \mathrm{~B}}{ }_{\mathrm{B}}$ mediates mechanical hyperalgesia through $\mathrm{G}_{\mathrm{q} / 11}$-phospholipase $\mathrm{C} \beta$ (PLC $\beta$ )-protein kinase $\mathrm{C} \varepsilon$ (PKCE) pathway. Interestingly, transient receptor potential vanilloid 1 (TRPV1) also involves in 5- $\mathrm{HT}_{2 B}$-mediated hyperalgesia. It was the first evidence that 5-HT receptor regulates TRP channel to affect mechanical hyperalgesia. It is a commentary on the recent article that suggests distinct roles of peptidergic ( $\mathrm{B}_{4}$-negative) and non-peptidergic ( $\mathrm{B}_{4}$-positive) nociceptors in regulating 5-HTinduced mechanical hyperalgesia. In $\mathrm{IB}_{4}$-negative neurons, $5-\mathrm{HT}_{2 \mathrm{~B}}$ in response to 5-HT mediates $\mathrm{PLC} \beta-\mathrm{PKC} \varepsilon$ to regulate TRPV1 function. In $\mathrm{IB}_{4}$-positive neurons, $5-\mathrm{HT}_{2 \mathrm{~B}}$ may control $5-\mathrm{HT}_{3}$ or other channels to regulate mechanical hyperalgesia.
\end{abstract}

Serotonin [5-hydroxytryptamine (5-HT)] is known as a neurotransmitter, which is involved in regulating transmission of nociceptive signals in central nerve system ${ }^{1}$. 5 - $\mathrm{HT}$ is also an inflammatory mediator, released from immune cells, platelets and epithelial cells in the peripheral tissues. Mounting evidence has suggested that 5-HT is a pro-inflammatory and pro-nociceptive agent which can cause pain and hyperalgesia through activating various subtypes of 5-HT receptors which are present in primary afferents $^{2,3}$. We previously demonstrated that 5-HT-induced mechanical hyperalgesia is attributed to $5-\mathrm{HT}_{2 \mathrm{~B}}$ activation ${ }^{4}$. Our recent article provided more detail mechanism that $5-\mathrm{HT}_{2 \mathrm{~B}}$ mediates $\mathrm{G}_{\mathrm{q} / 11}$-phospholipase $\mathrm{C} \beta$ (PLC $\beta$ )-protein kinase $\mathrm{C} \varepsilon(\mathrm{PKC} \varepsilon$ ) pathway to control mechanical hyperalgesia in both $\mathrm{IB}_{4}$-negative and -positive neurons. Interestingly, transient receptor potential vanilloid 1 (TRPV1) and $5-\mathrm{HT}_{3}$ are also regulated by $5-\mathrm{HT}_{2 \mathrm{~B}}$ to participate in 5-HT-induced mechanical hyperalgesia.

The distinct roles of $\mathrm{IB}_{4}$-negative and $\mathrm{IB}_{4}$-positive neurons in 5-HT-induced mechanical hyperalgesia

Pain transduction from the periphery to central nerve system depends on $\mathrm{A} \delta$ and $\mathrm{C}$ fiber sensory neurons ${ }^{5}$. C-fiber sensory neurons can be divided into two classes depended on their molecular properties. The peptidergic c-fiber expresses the neuropeptides calcitonin gene-related peptide (CGRP) and substance P (SP). The non-peptidergic c-fiber binds Isolectin $\mathrm{B}_{4}\left(\mathrm{IB}_{4}\right)$ and expresses glia 
cell-derived neurotrophic factor receptors (GDNF) and $\mathrm{P} 2 \mathrm{X} 3$ receptors ${ }^{6} . \mathrm{IB}_{4}$-negative neurons have low action potential (AP) threshold and shorter AP duration than $\mathrm{IB}_{4}^{-}$ positive neurons ${ }^{7}$. $\mathrm{IB}_{4}$-negative neurons are more important in transducing information about stimuli. Consistent with that 5-HT injection dramatically enhanced 5-HT-evoked intracellular calcium signals in IB4-negative neurons, but not in $\mathrm{IB}_{4}$-positive neurons. Therefore, $\mathrm{IB}_{4}$-negative neurons are the major neurons responsible for transducing 5-HT stimuli to induce mechanical hyperalgesia. Blocking $5-\mathrm{HT}_{2 \mathrm{~B}^{\prime}}$ PLC $\beta$ or PKC $\varepsilon$ before 5-HT injection inhibited the enhanced calcium signals in $\mathrm{IB}_{4}$-negative neurons. It is correlated with behavioral results that blocking of $5-\mathrm{HT}_{2 \mathrm{~B}}$ PLC $\beta$-PKC $\varepsilon$ pathway inhibited mechanical hyperalgesia.

Although $\mathrm{IB}_{4}$-positive neurons did no increases intracellular calcium signals after 5-HT injection, the number of the neurons responding to 5 -HT was increased. $\mathrm{IB}_{4}$-positive neurons with higher density of tetrodotoxin ((TTX)-resistant $\mathrm{Na}+$ channel and longer AP could lead more efficient calcium influx into the presynaptic terminal, resulting in more transmitter release ${ }^{8}$. $\mathrm{IB}_{4}$-positive neurons mediating more reliable synaptic connection could participate maintenance of hyperalgesia. As expected, blocking $5-\mathrm{HT}_{2 \mathrm{~B}}$, PLC $\beta$ or PKCe before 5-HT injection also inhibited the calcium signals in $\mathrm{IB}_{4}$-positive neurons.

In $\mathrm{IB}_{4}$-negative neurons, 5-HT-induced calcium signals were inhibited by removal of extracellular calcium; while only some of $\mathrm{IB}_{4}$-positive neurons were sensitive to calcium-free condition. It indicated that channels allow calcium influx may participate in 5-HT-induced calcium signals. TRPV1 and 5- $\mathrm{HT}_{3}$ are identified to participate in the downstream of $5-\mathrm{HT}_{2 \mathrm{~B}}$-mediated signaling pathway in $\mathrm{IB}_{4}$-positive and $\mathrm{IB}_{4}$-negative neurons, respectively.

Participation of TRPV1 in 5-HT signaling transduction in $\mathrm{IB}_{4}$-negative neurons: contribution to induction of mechanical hyperalgesia

TRPV1 is known as a heat and capsaicin receptor which is widely expressed in sensory neurons, especially in c-fiber nociceptors. TRPV1 is expressed both in peptidergic and non-peptidergic c-fiber in rat but predominantly in peptidergic c-fiber in mouse by immunohistochemical analysis ${ }^{9,10}$. Although capsaicin-induced calcium signals were greater in $\mathrm{IB}_{4}$-positive neurons than in $\mathrm{IB}_{4}$-negative neurons before 5-HT injection, capsaicin-evoked calcium signals were significantly enhanced in $\mathrm{IB}_{4}$-negative neurons after 5 -HT injection. Therefore, capsaicin-sensitive $\mathrm{IB}_{4}$-negative neurons may play a role in 5-HT-induced mechanical hyperalgesia under regulation of $5-\mathrm{HT}_{2 \mathrm{~B}}-\mathrm{PKC} \varepsilon$.

As confirmed in animal behavioral studies, administration of a TRPV1 antagonist before 5-HT injection in mice inhibited 5-HT-induced mechanical hyperalgesia. Mice lacking TRPV1 genes also showed the absence of mechanical hyperalgesia after 5-HT injection. Even though TRPV1 participates in thermal hyperalgesia, several lines of evidence have also suggested that the involvement of TRPV1 in capsaicin, acid or CFA-induced mechanical hyperalgesia which indicated the involvement of TRPV1 in mechanical hyperalgesia ${ }^{11,12}$. In those studies, TRPV1 is activated either by acid or by capsaicin. Despite that TRPV1 function is enhanced by 5 -HT through PKA and PKC phosphorylation ${ }^{13,14}$. However, no evidence demonstrated that TRPV1 can be activated by 5-HT. How $5-\mathrm{HT}_{2 \mathrm{~B}}$ regulates TRPV1 function remains unclear. In addition to being activated by allyl-isothiocyanate, capsaicin, acid, noxious heat and the pungent compound in mustard and wasabi, TRPV1 can be activated by some endogenous ligands. Anandamide (AEA), an endogenous fatty acid neurotransmitter derived from arachidonic acid (AA), can bind to and activate cannabinoid CB1 and $\mathrm{CB} 2$ receptors ${ }^{15}$. The AEA is generated from $\mathrm{N}$-acylphosphotidylethanolamides (NAPE) through phospholipase C-mediated hydrolysis ${ }^{16}$ and is reported to activate TRPV $1^{17}$. The data give one possible way that activation of $5-\mathrm{HT}_{2}$ receptor may mediate PLC leading AEA formation to activate TRPV1. Arachidonic acid (AA) is the precursor that can be metabolized by various enzymes. The products of lipoxygenase include 12- and 15-HEPETE, and 5-HETE that are also TRPV1 agonists ${ }^{18} .5-\mathrm{HT}_{2 \mathrm{~B}}$ receptor activation activate phospholipase $\mathrm{A} 2$, leading the neuronal secretion of $\mathrm{AA}^{19}$. Therefore, peripheral $5-\mathrm{HT}_{2 \mathrm{~B}}$ activation by 5-HT may relieve phosphatidylinositol 4,5-bisphosphatedependent channel inhibition and generates endogenous ligands AEA or AA to activate and regulate peripheral TRPV1 function, resulting in mechanical hyperalgesia.

Participation of 5- $\mathrm{HT}_{3}$ in 5-HT-induced calcium signal in $\mathrm{IB}_{4}$-positive neurons: contribution to maintenance of mechanical hyperalgesia

The calcium signals in $\mathrm{IB}_{4}$-negative neurons were completely dependent on $5-\mathrm{HT}_{2 \mathrm{~B}}-\mathrm{PLC} \beta-\mathrm{PKC} \varepsilon$ signaling and TRPV1 activation as described above. 5-HT-induced calcium signals in $\mathrm{IB}_{4}$-positive neurons were partially sensitive to removal of extracellular calcium, suggesting that the calcium signals may be from channels in both the plasma membrane and the endothelium reticulum (ER). 5- $\mathrm{HT}_{3}$ receptor antagonist (Granisetron) specifically inhibited 5-HT-induced calcium signals in a small set of $\mathrm{IB}_{4}-$ positive population, explaining sensitivity of these neurons to removal of extracellular calcium. Thus, there are at least two distinct pathways in $\mathrm{IB}_{4}$-positive neurons in response to 5-HT stimulation. One is 5- $\mathrm{HT}_{2 \mathrm{~B}}-\mathrm{PLC} \beta-\mathrm{PKC} \varepsilon$ pathway and the other is $5-\mathrm{HT}_{2 \mathrm{~B}}-\mathrm{PLC} \beta-\mathrm{PKC} \varepsilon / 5-\mathrm{HT}_{3}$ pathway.

$5-\mathrm{HT}_{3}$ was found in pain-related regions and is involved in pain processing ${ }^{20,21}$. In our previous study, mice with preinjection of $5-\mathrm{HT}_{3}$ antagonist did not inhibit mechanical hyperalgesia but shortened the duration of pain after $5-\mathrm{HT}$ 
injection ${ }^{4}$. Data from the recent article are consistent with the previous study by Lin et al., that $5-\mathrm{HT}_{3}$ is not involved in 5-HT-induced mechanical hyperalgesia ${ }^{1}$. However, the shortening of mechanical hyperalgesia suggests that $5-\mathrm{HT}_{3}$ may have an influence on modulating the maintenance of hyperalgesia. Stucky and Lewin ${ }^{7}$ suggested that $\mathrm{IB}_{4}$-positive neurons have a higher action potential (AP) threshold and longer AP duration than $\mathrm{IB}_{4}$-negative neurons. Also, there are some reports showing that $\mathrm{IB}_{4}$-positive neurons can exhibit sustained responses, but not transient or mixed responses to low $\mathrm{pH}^{22}$. Therefore, the responses in $\mathrm{IB}_{4}$ positve neurons that are sensitive to granisetron are thought to be responsible for extending the duration of 5-HT-induced mechanical hyperalgesia.

\section{The GPCR-TRP channel axis in 5-HT-induced pain and itch-like sensation}

In previous studies, 5-HT can induce pain and itch sensations in mice and humans ${ }^{23}$. A subset of 5-HTsensitive neurons is also sensitive to histamine and chloroquine, suggesting that these neurons are involved in itch perception ${ }^{24}$. A distinct subgroup of c-fibers that were preferentially excited by pruritic compounds has been reported ${ }^{25} \cdot 5-\mathrm{HT}_{2}$ receptors were reported to respond for 5-HT-induced itch through activating Gq/11-PLC pathway, which leads to mitogen-activate protein kinase (MAPK) and PKC activation ${ }^{26}$. GPCR-TRP channel pathways are the major pathways to itch responses. Similarly, 5-HT-induced mechanical hyperalgesia is also mediated by $5-\mathrm{HT}_{2 \mathrm{~B}}$-TRPV1 pathway. Our recent article also provides more detailed mechanisms about transduction and maintenance of pain signals. Transduction of noxious stimulation could be located at $\mathrm{IB}_{4}$-positive nociceptors and mediated by $5-\mathrm{HT}_{2 \mathrm{~B}}-5-\mathrm{HT}_{3}$ channel axis and $5-\mathrm{HT}_{2 \mathrm{~B}}$-second messenger pathways. The similarity of GPCR-TRP channel axis between pain and itch sensation suggests that mechanisms used in pain sensation are possibly involved in itch sensation.

\section{Conclusions}

The recent article demonstrated that peptidergic and non-peptidergic nociceptors mediate 5-HT signaling through distinct mechanisms to induce mechanical hyperalgesia. The axis of $5-\mathrm{HT}_{2 \mathrm{~B}}-\mathrm{Gq}-\mathrm{PLC} \beta-\mathrm{PKC} \varepsilon$-TRPV1 used in peptidergic neurons contributes to induction of hyperalgesia, while the axis of $5-\mathrm{HT}_{2 \mathrm{~B}}-\mathrm{Gq}-\mathrm{PLC} \beta-\mathrm{PKC} \varepsilon-5-\mathrm{HT}_{3}$ in non-peptidergic neurons participates in maintenance of hyperalgesia. The GPCR-TRP channel axis used in pain sensation could be also involved in itch sensation.

\section{References}

1. Riemsma R, Forbes C, Harker J, Worthy G, Misso K, Schäfer M, Kleijnen $\mathrm{J}$, and Stürzebecher S. Systemic review of tapentadol in chronic severe pain. Curr. Med. Res. Opin. 2011; 27: 1907-1930.

2. Taiwo YO, Heller PH, and Levine JD. Serotonin is a directly acting hyperalgesia agent in the rat. Neurosci. 1992; 48: 485- 490.
3. Schmelz M, Schmidt $R$, Weidner C, Hilliges $M$, Torebjork HE, Handwerker HO. Chemical response pattern of different classes of C-nociceptors to pruritogens and algogens. J. Neurophysiol. 2003; 89: 2441-2448

4. Lin SY, Chang WJ, Lin CS, Huang CY, Wang HF, Sun WH. Serotonin receptor 5-HT2B mediates serotonin-induced mechanical hyperalgesia. J Neurosci. 2011; 31: 1410-1418.

5. Su YS, Sun WS, Chen CC. Molecular mechanism of inflammatory pain World J. Anesthesiol. 2014; 27: 71-81.

6. Basbaum AI, Bautista DM, Scherrer G, Julius D. Cellular and molecular mechanisms of pain. Cell Rev. 2009; 139: 267-284.

7. Snape A, Pittawa JF, Baker MD. Excitability parameters and sensitivity to anemone toxin ATX-II in rat small diameter primary sensory neurones discriminated by Griffonia simplicifolia isolectin IB4. J Physiol. 2010; 588: 125-137.

8. Park D and Dunlap K. Dynamic regulation of calcium influx by G-proteins, action potential waveform, and neuronal firing frequency. J Neurosci. 1998; 18: 6757-6766.

9. Tominaga M, Caterina MJ, Malmberg AB, Rosen TA, Gilbert H, Skinner K, Raumann BE, Basbaum AI, Julius D. The cloned capsaicin receptor integrates multiple pain-producing stimuli. Neuron. 1998; 21: 531543.

10. Zwick M, Davis BM, Woodbury CJ, Burkett JN, Koerber HR, Simpson JF, Albers KM. Glial cell linederived neurotrophic factor is a survival factor for isolectin B4-positive, but not vanilloid receptor-positive, neurons in the mouse. J. Neurosci. 2002; 22: 4057-4065.

11. Caterina MJ, Leffler A, Malmberg AB, Martin WJ, Trafton J, PetersenZeitz KR, Koltzenburg M, Basbaum AI, Julius D. Impaired nociception and pain sensation in mice lacking the capsaicin receptor. Science. 2000; 288: 306-313.

12. Davis JB, Gray J, Gunthorpe MJ, Hatcher JP, Davey PT, Overend P, Harries MH, Latcham J, Clapham C, Atkinson K, Hughes SA, Rance K, Grau E, Harper AJ, Pugh PL, Rogers DC, Bingham S, Randall A, Sheardown SA. Vanilloid receptor-1 is essential for inflammatory thermal hyperalgesia. Nature. 2000; 405: 183-187.

13. Sugitar T, Bielefeldt K, Gebhart GF. TRPV1 function in mouse colon sensory neurons is enhanced by metabotropic 5-hydroxytryptamine receptor activation. J. Neurosci. 2004; 24: 9521-9530.

14. Ohta $\mathrm{T}$, Ikemi $\mathrm{Y}$, Murakami $\mathrm{M}$, Imagawa $\mathrm{T}$, Otsuguro $\mathrm{K}$, Ito $\mathrm{S}$. Potentiation of transient receptor potential V1 functions by the activation of metabotropic 5-HT receptors in rat primary sensory neurons. J. Physiol. 2006; 576: 809-822.

15. Pertwee RG, Howlett AC, Abood ME, Alexander SP, Di Marzo V, Elphick MR, Greasley PJ, Hansen HS, Kunos G, and Mackie K et al. Cannabinoid receptors and their ligands: beyond $\mathrm{CB}_{1}$ and $\mathrm{CB}_{2}$. Pharm. Rev. 2010; 62: 588-631.

16. Liu J, Wang L, Harvey-white J, Huang BX, Kim HY, Luquet S, Palmiter RD, Krystal G, Rai R, Mahadevan A, Razdan RK, and Kunos G. Multiple pathways involved in the biosynthesis of anandamide. Neuropharm. 2008; 54: 1-7.

17. Di Marzo V, Bisogno T, \& De Petroellis L. Anandamide: some like it hot. Trends Pharmacol. Sci. 2001; 22: 346-349.

18. Kelly S, Chapman RJ, Woodhams S, Sagar DR, Turner J, Burston JJ, Bullock C, Paton K, Huang J, Wong A, Mcwilliams DF, Okine BN, Barrett DA, Hathway GJ, Walsh DA and Chapman V. Increased function of pronociceptive TRPV1 at the level of the joint in a rat model of osteoarthritis pain. Ann Rheum Dis. 2015; 74: 252-259.

19. Tournois C, Mutel V, Manivet P, Launay JM, and Kellermann O. Crosstalk between 5-hydroxytryptamine receptors in a serotonergic cell line. J. Biol. Chem. 1998; 273: 17498-17503. 
20. Zeitz KP, Guy N, Malmberg AB, Dirajlal S, Martin WJ, Sun L, et al The $5-\mathrm{HT}_{3}$ subtype of serotonin receptor contributes to nociceptive processing via a novel subset of myelinated and unmyelinated nociceptors. J Neurosci. 2002; 22: 1010-1019.

21. Hall JD, Dewitte C, Ness TJ, Robbins MT. Serotonin enhances urinary bladder nociceptive processing via a $5-\mathrm{HT}_{3}$ receptor mechanism. Neurosci. Lett. 2015; 604: 97-102.

22. Petruska JC, Napaporn J, Johnson RD, and Cooper BY. Chemical responsiveness and histochemical phenotype of electrophysiologically classified cells of the adult rat dorsal root ganglion. Neurosci. 2002; 115: 15-30.
23. McNeil B, Dong X. Peripheral mechanism of itch. Neurosci Bull. 2012; 28: $100-110$.

24. Akiyama T, Carstens MI, Carstens E. Facial injections of pruritogens and algogens excite partly overlapping populations of primary and second-order trigeminal neurons in mice. J Neurophysiol. 2010; 104 : 2442-2450.

25. Schmelz M. Itch and pain. Neurosci. Biobehav. Rev. 2010; 34: 171-176.

26. Yamaguchi T, Nagasawa T, Satoh M, and Kuraishi Y. Itch associated response induced by intradermal serotonin through $5-\mathrm{HT}_{2}$ receptors in mice. Neurosci. Res. 1999; 35: 77-83. 